\title{
CORRECTION
}

\section{Correction to: Review of Machine Learning Techniques for EEG Based Brain Computer Interface}

\author{
Swati Aggarwal ${ }^{1} \cdot$ Nupur Chugh $^{2} \mathbb{C}$
}

Published online: 29 December 2021

(c) The Author(s) under exclusive licence to International Center for Numerical Methods in Engineering (CIMNE) 2021

\section{Correction to: \\ Archives of Computational Methods in Engineering \\ https://doi.org/10.1007/s11831-021-09684-6}

This erratum is published as article as author affiliations were incorrectly mentioned.

Affiliation of first author should be read as Netaji Subhas University of Technology.

Original article has been updated.

Publisher's Note Springer Nature remains neutral with regard to jurisdictional claims in published maps and institutional affiliations.

The original article can be found online at https://doi.org/10.1007/ s11831-021-09684-6.

Nupur Chugh

nupur.chugh@gmail.com

1 Netaji Subhas University of Technology (Formerly Netaji

Subhas Institute of Technology), New Delhi, India

2 Netaji Subhas Institute of Technology, New Delhi, India 